\title{
Assessing the Impact of INSPIRE on Related EU Marine Directives
}

Roger LONGHORN, Belgium

The Coastal \& Marine Union (EUCC)

Topic: D Smart data management, E Easy customer access to data and products, G Cost-effective solutions

\section{INTRODUCTION}

The EU's INSPIRE Directive (EC 2007a) is to create a pan-European Spatial Data Infrastructure (SDI) focused on environmental data. INSPIRE's implementing EC Regulations and EU Decisions are intended to provide data harmonization and information services interoperability for spatial data required by many other EU Directives. In the marine community, INSPIRE has been proposed as the supporting SDI for the Water Framework Directive - WFD (EC 2000), the Marine Strategy Framework Directive - MSFD (EC 2008a), the Flood Risk Assessment Directive (EC 2007b), and other environmentally oriented Directives in many different areas, e.g. air quality, noise, health, etc. INSPIRE harmonized data is also expected to support the principles and data requirements of the Water Information System for Europe (WISE) (water.europa.eu) and its marine component (WISEMarine) (webgate.ec.europa.eu/maritimeforum/category/554) as well as the Shared Environmental Information System (SEIS) (EC 2008b).

Oneo of the goals of these initiatives is to reduce the level of paper-based reporting required of EU Member States, to be replaced by online reporting using harmonized datasets. Another goal is to enhance the automated data sharing capabilities between Member States and EU institutions, such as different European Commission Directorates-General (DG Environment, DG Maritime Affairs and Fisheries) and the European Environment Agency (EEA).

The proposed reliance on INSPIRE to support the environmental monitoring and reporting requirements set out in these Directives raises two challenges. Firstly, much of the environmental geospatial information required for reporting, in order to be compliant with the other Directives, is not required to be harmonized under the INSPIRE Directive until between 2015 and 2020, long after that information is needed for both initial and later reporting for some of the Directives. Secondly, the data that is required to be harmonized according to INSPIRE and its Regulations is not always as comprehensive as that required for reporting by the environmental Directives themselves.

\section{INSPIRE AND THE MARINE COMMUNITY}

The INSPIRE Directive addresses 34 data themes that are considered to have a direct of indirect impact on the environment. The full list of themes is shown in Table 1, along with an indication of how relevant each theme may be to the broadly diverse marine/coastal management and research communities. As you can see, 20 of the 34 data themes covered by INSPIRE are relevant to different marine/coastal management and research communities. Of these, ten are considered to be highly relevant, and deal with what could be considered to be primary marine/coastal data.

Table 1: INSPIRE Data Themes and Relevance to Marine/Coastal Information

Scale: 1 = very relevant; 2 = relevant; 3 = less directly relevant

\begin{tabular}{|l|c|}
\hline \multicolumn{1}{|c|}{ INSPIRE Directive Data Themes } & Relevance \\
\hline \multicolumn{1}{|c|}{ Annex I } & $\mathbf{1}$ \\
\hline $\begin{array}{l}\text { Hydrography - Hydrographic elements, including marine areas and all other water } \\
\text { bodies and items related to them, including river basins and sub-basins. }\end{array}$ & $\mathbf{1}$ \\
\hline $\begin{array}{l}\text { Protected sites - Area designated or managed within a framework of international, } \\
\text { Community and Member States' legislation to achieve specific conservation objectives. }\end{array}$ & \\
\hline
\end{tabular}




\begin{tabular}{|c|c|}
\hline (marine protected areas?) & \\
\hline $\begin{array}{l}\text { Administrative units - Units of administration, dividing areas where Member States } \\
\text { have and/or exercise jurisdictional rights, for local, regional and national governance, } \\
\text { separated by administrative boundaries. (now proposed to model marine zones in this } \\
\text { theme as opposed to Sea Regions or Area Management) }\end{array}$ & $\mathbf{1}$ \\
\hline $\begin{array}{l}\text { Geographical grid systems - Harmonised multi-resolution grid with a common point } \\
\text { of origin and standardised location and size of grid cells. (for reporting fisheries } \\
\text { statistics and MSFD indicators?) }\end{array}$ & 1 \\
\hline Annex II & \\
\hline $\begin{array}{l}\text { Elevation - Digital elevation models for land, ice and ocean surface. Includes terrestrial } \\
\text { elevation, bathymetry and shoreline. (shoreline excluded from Elevation - now modelled } \\
\text { in Sea Regions) }\end{array}$ & 1 \\
\hline $\begin{array}{l}\text { Geology - Geology characterised according to composition and structure. Includes } \\
\text { bedrock, aquifers and geomorphology. (seabed sediments modelling; coastal } \\
\text { geomorphology) }\end{array}$ & 1 \\
\hline $\begin{array}{l}\text { Land cover - Physical and biological cover of the earth's surface including artificial } \\
\text { surfaces, agricultural areas, forests, (semi-) natural areas, wetlands, water bodies. }\end{array}$ & 2 \\
\hline Annex III & \\
\hline $\begin{array}{l}\text { Area management/restriction/regulation zones and reporting units - Areas } \\
\text { managed, regulated or used for reporting at international, European, national, regional } \\
\text { and local levels. Includes dumping sites, restricted areas around drinking water sources, } \\
\text { nitrate-vulnerable zones, regulated fairways at sea or large inland waters, areas for the } \\
\text { dumping of waste, noise restriction zones, prospecting and mining permit areas, river } \\
\text { basin districts, relevant reporting units and coastal zone management areas. }\end{array}$ & 1 \\
\hline $\begin{array}{l}\text { Agricultural and aquaculture facilities - Farming equipment and production } \\
\text { facilities. }\end{array}$ & 1 \\
\hline $\begin{array}{l}\text { Environmental monitoring facilities - Location and operation of environmental } \\
\text { monitoring facilities includes observation and measurement of emissions, of the state of } \\
\text { environmental media and of other ecosystem parameters (biodiversity, ecological } \\
\text { conditions of vegetation, etc.) by or on behalf of public authorities. }\end{array}$ & 2 \\
\hline $\begin{array}{l}\text { Natural risk zones - Vulnerable areas characterised according to natural hazards (all } \\
\text { atmospheric, hydrologic, seismic, volcanic and wildfire phenomena that, because of } \\
\text { their location, severity, and frequency, have the potential to seriously affect society), } \\
\text { e.g. floods, landslides and subsidence, avalanches, forest fires, earthquakes, volcanic } \\
\text { eruptions. }\end{array}$ & 2 \\
\hline $\begin{array}{l}\text { Oceanographic geographical features - Physical conditions of oceans (currents, } \\
\text { salinity, wave heights, etc.). }\end{array}$ & 1 \\
\hline $\begin{array}{l}\text { Sea regions - Physical conditions of seas and saline water bodies divided into regions } \\
\text { and sub-regions with common characteristics. }\end{array}$ & $\mathbf{1}$ \\
\hline $\begin{array}{l}\text { Energy resources - Energy resources including hydrocarbons, hydropower, bio- } \\
\text { energy, solar, wind, etc., where relevant including depth/height information on the } \\
\text { extent of the resource. (offshore wind farms) }\end{array}$ & 2 \\
\hline $\begin{array}{l}\text { Mineral resources - Mineral resources including metal ores, industrial minerals, etc., } \\
\text { where relevant including depth/height information on the extent of the resource. (off } \\
\text { shore extraction) }\end{array}$ & 2 \\
\hline $\begin{array}{l}\text { Habitats and biotopes - Geographical areas characterised by specific ecological } \\
\text { conditions, processes, structure, and (life support) functions that physically support the } \\
\text { organisms that live there. Includes terrestrial and aquatic areas distinguished by } \\
\text { geographical, abiotic and biotic features, whether entirely natural or semi-natural. }\end{array}$ & 2 \\
\hline $\begin{array}{l}\text { Species distribution - Geographical distribution of occurrence of animal and plant } \\
\text { species aggregated by grid, region, administrative unit or other analytical unit. (relevant } \\
\text { to MSFD reporting) }\end{array}$ & 2 \\
\hline Bio-geographical regions - Areas of relatively homogeneous ecological conditions & 3 \\
\hline
\end{tabular}


with common characteristics.

Utility and governmental services - Includes utility facilities such as sewage, waste management, energy supply and water supply, administrative and social governmental services such as public administrations, civil protection sites, schools and hospitals.

Production and industrial facilities - Industrial production sites, including installations covered by Council Directive 96/61/EC of 24 September 1996 concerning integrated pollution prevention and control and water abstraction facilities, mining, storage sites.

Many of these themes cover data that are needed for monitoring and reporting on different marine, coastal or oceanic environmental themes as required by other EC Directives, as indicated in Table 2 . Note that most of these Directives and their implementing EC Regulations pre-date the INSPIRE Directive itself. Their associated reporting monitoring and/or requirements certainly predate the date(s) by which the harmonized data is to be avaialble as a result of INSPIRE implementation, as indicated in the INSPIRE Road Map shown in Table 4.

Table 2: EU Directives, Decisions and Communications impacting the marine/coastal environments and related environmental information initiatives (date order)

\section{Legislative}

DIRECTIVE 92/43/EEC of 21 May 1992 on the conservation of natural habitats and of wild fauna and flora (Annex I - 1. Coastal and Halophytic Habitats).

DIRECTIVE 2000/60/EC OF THE EUROPEAN PARLIAMENT AND OF THE COUNCIL of 23 October 2000 establishing a framework for Community action in the field of water policy (the 'Water Framework Directive').

RECOMMENDATION OF THE EUROPEAN PARLIAMENT AND OF THE COUNCIL of 30 May 2002 concerning the implementation of Integrated Coastal Zone Management in Europe (the 'ICZM Recommendation').

- $\operatorname{COM(2007)} 308$ final of 7 June 2007 - Report to the European Parliament and the Council: An evaluation of Integrated Coastal Zone Management (ICZM) in Europe.

DIRECTIVE 2006/7/EC OF THE EUROPEAN PARLIAMENT AND OF THE COUNCIL of 15 February 2006 concerning the management of bathing water quality and repealing Directive 76/160/EEC.

DIRECTIVE 2006/11/EC OF THE EUROPEAN PARLIAMENT AND OF THE COUNCIL of 15 February 2006 on pollution caused by certain dangerous substances discharged into the aquatic environment of the Community (the 'Water Protection Directive').

DIRECTIVE 2006/113/EC OF THE EUROPEAN PARLIAMENT AND OF THE COUNCIL of 12 December 2006

on the quality required of shellfish waters.

DIRECTIVE 2007/60/EC OF THE EUROPEAN PARLIAMENT AND OF THE COUNCIL of 23 October 2007 on the assessment and management of flood risks.

DIRECTIVE 2008/56/EC OF THE EUROPEAN PARLIAMENT AND OF THE COUNCIL of 17 June 2008 establishing a framework for community action in the field of marine environmental policy (Marine Strategy Framework Directive).

- DECISION (2010/477/EU) of 1 September 2010 on criteria and methodological standards on good environmental status of marine waters (implements the MSFD). 
REGULATION (EU) No 1255/2011 OF THE EUROPEAN PARLIAMENT AND OF THE COUNCIL of 30 November 2011 establishing a Programme to support the further development of an Integrated Maritime Policy.

- $\operatorname{COM(2010)} 494$ final of 29 September 20120 - Proposal for a Regulation establishing a Programme to support the further development of an Integrated Maritime Policy.

\section{Communications (Advisory Policy)}

COM(2010) 461 final of 8 September 2010 MARINE KNOWLEDGE 2020 - marine data and observation for smart and sustainable growth.

\section{EC Regional Marine Information Projects}

DG MARE - European Marine Observation Network (EMODnet)

SeaDataNet (FP6) - marine information metadata standards and data formats

NetMar(FP7) - marine information standards (European Marine Information System - EUMIS)

\section{Environmental Information Initiatives}

DG ENV - Shared Environmental Information System (SEIS)

DG ENV - Water Information System for Europe (WISE) and WISE-Marine

During development of the data specifications for INSPIRE, the relevant Thematic Working Groups of experts were also to take into consideration the existing requirements of 'international law', as per Article 7 of the Directive: "Where organisations established under international law have adopted relevant standards to ensure interoperability or harmonisation of spatial data sets and services, these standards shall be integrated, and the existing technical means shall be referred to, if appropriate, in the implementing rules mentioned in this paragraph." (EC 2007a, 6). This has proven to be difficult, given the number of such conventions that exist in the marine arena, as indicated in Table 3.

Table 3: International Marine/Maritime Treaties and Conventions affected by data being harmonised in INSPIRE and other initiatives

HELCOM - Baltic Marine Environment Protection Commission (Helsinki Commission) (Baltic Sea) [www.helcom.fi/home/en and www.helcom.fi/GIS/en_GB/HelcomGIS/ for maps)

OSPAR - OSPAR Commission, protecting and conserving the North-East Atlantic and its resources (North-east Atlantic divided into 5 regions - Arctic Waters, Greater North Sea, Celtic Seas, Bay of Biscay and Iberian Coast, Wider Atlantic) [www.ospar.org]

Barcelona Convention for the Protection of the Marine Environment and the Coastal Region of the Mediterranean) (to reduce pollution and protect/improve marine environment for sustainable development) [http://www.unep.ch/regionalseas/regions/med/t_barcel.htm]

Bucharest Convention (Convention on the Protection of the Black Sea Against Pollution) [http://www.blacksea-commission.org/main.asp]

- Protocols to the Convention on the Protection of the Black Sea Against Pollution

- Strategic Action Plan for the Environmental Protection and Rehabilitation of the Black Sea (2009)

- Black Sea Basin Joint Operational Programme (2007-2013) [www.blacksea-cbc.net]

ICES (International Council for the Exploration of the Sea) (global fisheries monitoring) [www.ices.dk/indexfla.asp]

UN FAO Fisheries Areas (relevant to Europe are: Arctic Sea, Atlantic-Northeast, Atlantic - Eastern Central, Mediterranean- and-Black Sea) [www.fao.org/fishery/area/search/en]

Other programmes for which EU coastal Member States may have responsibilities

UNEP Mediterranean Action Plan (UNEP/MAP) (http://www.unepmap.org/) 
The INSPIRE Directive was the result of preliminary environmental SDI work that began in 2000. The Directive was published in 2007 and all EU Member States were required to implement the Directive in national legislation by May 2009. All have now done so, however, many Member States have yet to even completely update the metadata for the Annex I and II datasets, which was required by end of December 2010.

Table 4 shows the date by which the INSPIRE Implementing Rules (IR) for the 25 Annex II and III data themes will be promulgated in 2013 as an amendment to the existing EC Regulation (EC 2010), which entered into force on 28 December 2010. Note that data reporting requirements for many of the Directives mentioned in the introduction occur prior to the INSPIRE harmonised data being available, under this roadmap.

Table 4: INSPIRE IR Adoption Roadmap

\begin{tabular}{|c|l|}
\hline Dates & \multicolumn{1}{|c|}{ Actions/Deliverables } \\
\hline 22 Sept 2012 & $\begin{array}{l}\text { Adoption Roadmap } \\
\text { Inter-service consultation of the draft Implementing Rules for INSPIRE Annex II and } \\
\text { III Data Specifications at the European Commission. }\end{array}$ \\
\hline 15 Oct 2012 & Draft IR/Regulation is sent to the INSPIRE Committee for review/approval. \\
\hline October 2013 & $\begin{array}{l}\text { Adoption of IRs for the interoperability of spatial data sets and services for Annex II } \\
\text { and III spatial data themes. }\end{array}$ \\
\hline & Implementation Roadmap \\
\hline 23-Nov-2012 & $\begin{array}{l}\text { Annex I spatial data sets to be available according to Commission Regulation (EU) } \\
\text { No 1089/2010 for existing data (9 data themes, including Hydrography) }\end{array}$ \\
\hline 28-Dec-2012 & Download \& Transformation services to be fully operational \\
\hline 03-Deb-2013 & $\begin{array}{l}\text { Annex I spatial data sets to be available according to Commission Regulation (EU) } \\
\text { No 1089/2010 for newly collected and extensively restructured Annex I spatial data } \\
\text { sets (9 themes) }\end{array}$ \\
\hline October 2015 & $\begin{array}{l}\text { Netadata available for spatial data sets and services corresponding to Annex III } \\
\text { available (25 data themes) }\end{array}$ \\
\hline 23-Nov-2017 & $\begin{array}{l}\text { Annex I spatial data sets to be available according to Commission Regulation (EU) } \\
\text { No 1089/2010 and Commission Regulation (EU) No 102/2011 of 4 February 2011 for } \\
\text { spatial data sets still in use at the date of adoption (9 themes) }\end{array}$ \\
04-Feb-2018 & $\begin{array}{l}\text { Other Annex II and III spatial data sets available in accordance with Implementing } \\
\text { Rules for Annex II and III data sets (25 data themes) }\end{array}$ \\
\hline October 2020
\end{tabular}

The latest information on the INSPIRE implementation roadmap can be found at: http://inspire.jrc.ec.europa.eu/index.cfm/pageid/44.

\section{RELATIONSHIPS BETWEEN INSPIRE AND OTHER DIRECTIVES}

Because the Water Framework Directive predated INSPIRE by many years, and also was the first EU Directive to include specific geographic information formats for reporting, its requirements were taken into consideration very well during development of the INSPIRE data specifications, especially for Hydrography and Area Management. Even so, there is talk that a future revision to the WFD will be needed and/or further extensions to INSPIRE in order to achieve the desired level of harmonised reporting envisioned when INSPIRE was proposed. 
INSPIRE faces a similar challenge with regard to the Marine Strategy Framework Directive for which the initial assessment reports of Good Environmental Status are due by mid-October this year (2012), yet much of the data needed in harmonised format is not required by INSPIRE until October 2015 or even October 2020. An analysis carried out during development of the INSPIRE data specification for Area Management indicated that some of the attributes required for MSFD reporting are not in current (version 3.0 - final) INSPIRE data specifications for the relevant themes. Also, some of the INSPIRE themes required are in Annex I and others are in Annex II or III, while compliance deadlines for data harmonisation in Annex I, II and III are different.

The Flood Risk Assessment Directive of 2007 sets out the timetable for compliance in Chapters VI and VIII. Chapter VI states "Member States shall ensure that flood risk management plans are completed and published by 22 December 2015." (EC 2007b, 31) while Chapter VIII states (EC 2007b, 33):

- "preliminary flood risk assessment ... shall be reviewed by 22 December 2018 ..."

- "flood hazard maps and the flood risk maps shall be reviewed by 22 December 2019 ..."

- "flood risk management plan(s) shall be reviewed by 22 December 2021".

This is one case where it is possible that harmonised, INSPIRE compliant data may be available in a timely manner, but determining whether all the data needed for such reporting is covered by INSPIRE is not as easily determined.

WISE-Marine is intended to be a "comprehensive and shared European data and information management system for the marine environment which supports implementation of the Marine Strategy Framework Directive. This will also include the use of the EMODnet and INSPIRE processes to establish the required infrastructure and data access." (EC DG Maritime Affairs 2012). As WISEMarine is a 'work in progress', and tied in to other reporting requirements, we cannot at this time realistically judge the impact that INSPIRE will have on success of the initiative.

EMODnet has been developing in parallel with INSPIRE, but not always in full concurrence, as the developers of EMODnet see a need for many more data attributes in a range of marine areas than have been considered in developing the INSPIRE data specifications.

\section{CONCLUSION}

One of the key challenges faced in using INSPIRE data and interoperable services is the timing mismatch between the dates by which INSPIRE data is to be available in a harmonized format and the dates by which existing Directives or Regulations already require reporting to be completed. Also, because the individual data specifications resulted in attributes (or features) to satisfy, in some cases, a wide range of users or sectors, even within a single theme, the final INSPIRE specification may not be sufficiently inclusive to permit the degree of paperless, online reporting envisioned by the SEIS or WISE-Marine initiatives, such as EMODnet. Possible solutions to the data challenges posed by attempts at pan-European data harmonisation and services interoperability will continue to be a challenge for the marine community throughout the coming decade - and perhaps longer.

\section{REFERENCES}

EC DG Maritime Affairs. 2012a. EMODnet - European Marine Observation and Data Network. https://webgate.ec.europa.eu/maritimeforum/category/160.

EC DG Maritime Affairs. 2012b. WISE-Marine.

https://webgate.ec.europa.eu/maritimeforum/category/554. 
EC, European Commission. 2000. Directive 2000/60/EC of the European Parliament and of the Council establishing a framework for the Community action in the field of water policy. Official Journal of the European Union, OJ L 327, 22/12/2000.

http://eur-lex.europa.eu/LexUriServ/LexUriServ.do?uri=OJ:L:2000:327:0001:0072:EN:PDF.

EC, European Commission. 2007a. Directive 2007/2/EC of the European Parliament and of the Council of 14 March 2007 establishing an Infrastructure for Spatial Information in the European Community (INSPIRE). Official Journal of the European Union, OJ L 108, 25/04/2007.

http://eur-lex.europa.eu/LexUriServ/LexUriServ.do?uri=OJ:L:2007:108:0001:0014:EN:PDF.

EC, European Commission 2007b. Directive 2007/60/EC of the European Parliament and of the Council of 23 October 2007 on the assessment and management of flood risks. Official Journal of the European Union, OJ L 288, 6/11/2007.

http://eur-lex.europa.eu/LexUriServ/LexUriServ.do?uri=OJ:L:2007:288:0027:0034:en:pdf

EC, European Commission. 2008a.Directive 2008/56/EC of the European Parliament and of the Council of 17 June 2008 establishing a framework for community action in the field of marine environmental policy (Marine Strategy Framework Directive). Official Journal of the European Union, OJ L 164, 25/6/2008.

http://eur-lex.europa.eu/LexUriServ/LexUriServ.do?uri=OJ:L:2008:164:0019:0040:EN:PDF

EC, European Commission. 2008b. Communication from the Commission to the Council, the European Parliament, the European Economic and Social Committee and the Committee of the Regions Towards a Shared Environmental Information System (SEIS). COM (2008) 46 final, Brussels, $1 / 2 / 2008$.

http://eur-lex.europa.eu/LexUriServ/LexUriServ.do?uri=COM:2008:0046:FIN:EN:PDF

EC, European Commission. 2010. EC Regulation 1089/2010 of 23 November 2010 implementing Directive 2007/2/EC of the European Parliament and of the Council as regards interoperability of spatial data sets and services published on 8 December 2010. Official Journal of the European Union, OJ L 323, 8/12/2010.

http://eur-lex.europa.eu/LexUriServ/LexUriServ.do?uri=OJ:L:2010:323:0011:0102:EN:PDF

\section{BIOGRAPHIES}

Roger LONGHORN is Information Policy Advisor to the Coastal \& Marine Union (EUCC), lecturer on Marine SDI and communications at the UNESCO Intergovernmental Oceanographic Commission's Ocean Teacher Academ, and an expert in SDI development in the EU and globally since 1995. A graduate of the Massachusetts Institute of Technology in Ocean Engineering (BSc) and Shipping Management (MSc), Roger has long association with the marine transport and science communities since 1976 and represents EUCC on the INSPIRE Thematic Working Group 'Area Management' developing the data specifications for the INSPIRE Directive, including coastal zone management.

\section{CONTACT DETAILS}

\section{Roger LONGHORN}

The Coastal \& Marine Union (EUCC)

Fazantenlaan 24

Bredene

BELGIUM

Tel.: +32 59435396

Fax: +32 59795228

Email: ral@alum.mit.edu

Web site: www.eucc.net 